\title{
Magnetic data evidence of a likely new alkaline intrusion at Canoas beach, Ponta Grossa Arch Alkaline Province, southern Brazil
}

Ferreira, F.J.F., LPGA-UFPR; Szameitat, L.S.A., LPGA-UFPR; Castro, L.G., Civil Engineering Department-Universidade Positivo (UP); Silva, V.A.F., LPGA-UFPR; Weihermann, J.D., LPGA-UFPR

Copyright 2018, SBGf - Sociedade Brasileira de Geofísica

Este texto foi preparado para a apresentação no VIII Simpósio Brasileiro de Geofísica, Salinópolis, 18 a 20 de setembro de 2018. Seu conteúdo foi revisado pelo Comitê Técnico do VIII SimBGf, mas não necessariamente representa a opinião da SBGf ou de seus associados. É proibida a reprodução total ou parcial deste material para propósitos comerciais sem prévia autorização da SBGt.

\section{Abstract}

Several alkaline bodies were recognized in Ponta Grossa Arch Alkaline Province (PGAAP). On magnetic maps, they usually occur as dipolar anomalies with normal polarization. At Canoas beach, the recent high-resolution magnetic data allowed us to determine an unregistered dipolar anomaly, with a reverse polarization, which is similar to the Juquiá alkaline intrusion. In this work, we use filtered maps and Euler deconvolution to first characterize this magnetic anomaly. Ground gravimetric and magnetic profiles corroborate the airborne anomaly. We notice that the magnetic source seems to be rounded on maps, as well as deep-rooted. The observed characteristics are suggestive of a pipe-like body in agreement with magnetic signature of other alkaline occurrences on PGAAP.

\section{Introduction}

The Ponta Grossa Arch (PGA) is a large structure on Southeastern Paraná Basin. It can be described as an NWSE uplifted domain, which holds a large number of tholeiitic diabase dykes and alkaline pipe-like occurrences (Fig. 1), related to magmatic events in the Paraná Basin (Ferreira, 1982; Almeida, 1983, 1986; Riccomini et al., 2005). Both dykes and alkaline rocks are well sighted on magnetic maps, as shown in Figure 2. The PGA has four major geological-geophysical lineaments, that were named as Guapiara, São Jerônimo-Curiúva, Rio Alonzo and Rio Piquiri (Ferreira, 1982), as presented in Figure 1.

Ponta Grossa Arch Alkaline Province (PGAAP) was defined by Almeida (1983) and assemble alkaline occurrences that may be controlled by the PGA megastructure. Using age and petrological data, PGAAP was divided into two subprovinces, related to Guapiara and São Jerônimo-Curiúva lineaments (Ferreira et al., 1984). The Guapiara Subprovince is the northernmost domain and envolves Jacupiranga, Juquiá, Pariquera-Açú, and Cananéia occurrences (e.g. Gomes et al., 2018). To the south, several alkaline bodies were attributed to the São Jerônimo-Curiúva Subprovince (Fig. 1). Thereafter,
Riccomini et al. (2005) expanded the PGAAP, including Ipanema, Salto de Pirapora, Piedade and Itanhaém alkaline bodies in the São Paulo State. In the Southern PGAAP, they included Anitapólis, in the Santa Catarina State. Ruberti et al. (2005), Almeida et al. (2017), and Gomes et al. (2018) describe PGAAP's petrological and petrochemical data in detail.

Magnetic sources typically generate narrow dipolar magnetic anomalies, and most of them display normal polarity (e.g. Ferreira and Algarte, 1979; Marangoni and Mantovani, 2013). However, some magnetic anomalies have reverse polarity, such as Juquiá (Ernesto and Marques, 2000; Slavec et al., 2001) and Canoas, from this work.

\section{Methods}

The high-resolution aeromagnetic data were acquired by CPRM (2011), along north-south flight lines spaced at 500 $\mathrm{m}$, with a mean terrain clearance of $100 \mathrm{~m}$. The tie lines have $10 \mathrm{~km}$ spacing.

The Analytical Signal Amplitude (ASA) filter is used to provide the magnetic anomaly location over the magnetic source, avoiding the use of declination and inclination of remnant vector (Nabighian, 1972; Blakely, 1996). Also, it is used to estimate source boundaries (Blakely, 1996). Nevertheless, the final result will depend of the 3D source geometry and extension, in relation to the magnetic field (Li, 2006).

In addition, the vertical integral of ASA (VIAS) is used in order to highlight the deep part of the magnetic source. The vertical integration effect is similar to the upward continuation. However, it better preserves geological contacts (Silva, 1996). Once applied to ASA, the vertical integration product must be similar to the estimated original non-remnant anomaly (Paine et al., 2001).

As a result, VIAS transformed data encloses the ASA data, producing a more continuous anomaly. Moreover, VIAS unit is $\mathrm{nT}$, which improves its application for magnetic modelling (Paine et al., 2001).

Furthermore, we use Euler Deconvolution method (Thompson, 1982) to analyze ASA and VIAS transformed data in order to obtain a first estimation of source depths. 


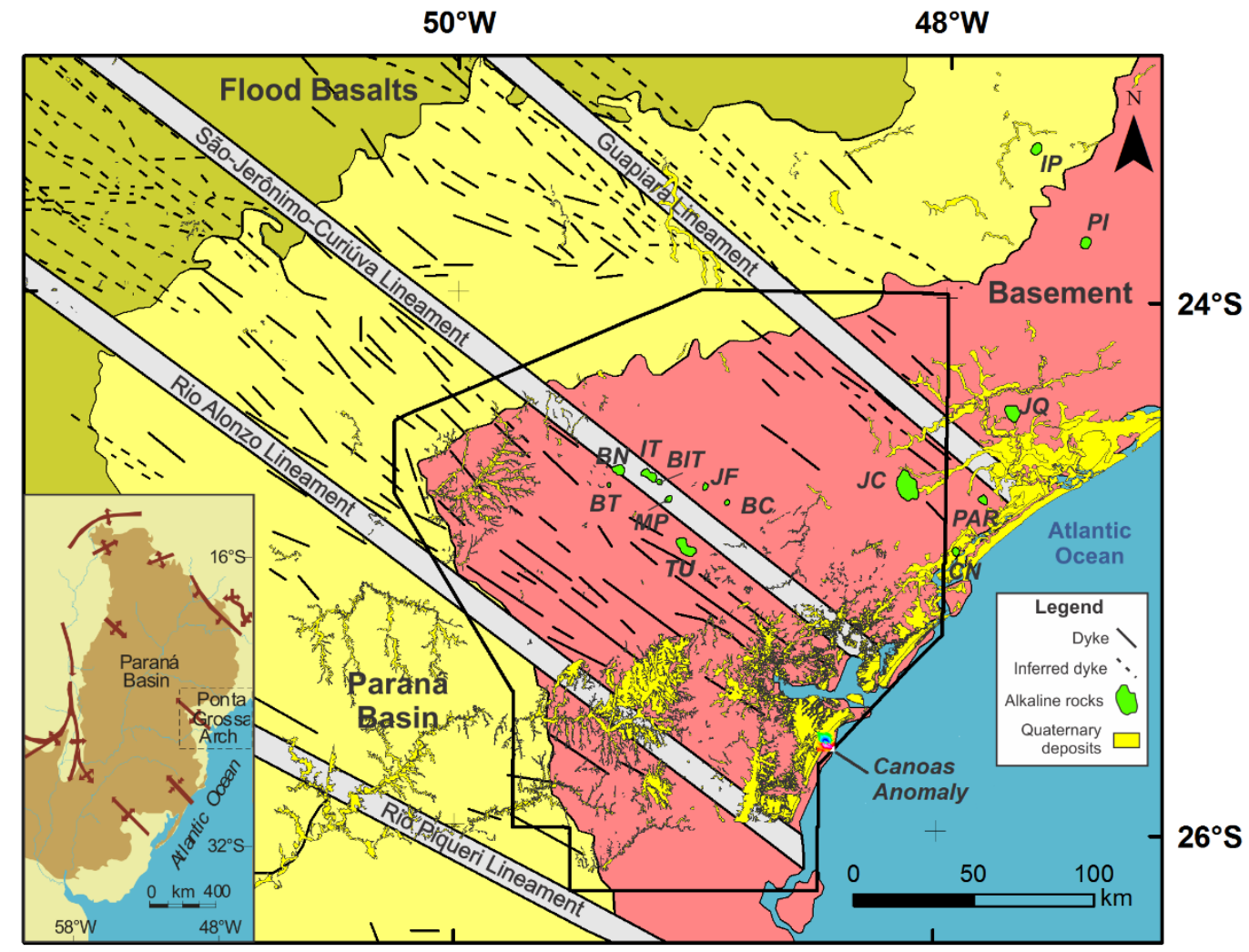

Figure 1 - Sketch map of the Ponta Grossa Arch Alkaline Province and Canoas Anomaly (modified from Ruberti et al., 2005 and Gomes et al., 2018). Alkaline occurrences: BC, Bairro da Cruz; BIT, Barra do Itapirapuã; BN, Banhadão; BT, Barra do Teixeira; CN, Cananéia; IP, Ipanema; IT, Itapirapuã; JC, Jacupiranga; JF, José Fernandes; JQ, Juquiá; MP, Mato Preto; PAR, Pariquera-Açu; PI, Piedade; TU, Tunas. The black polygon indicates the aeromagnetic data in Figure 2.

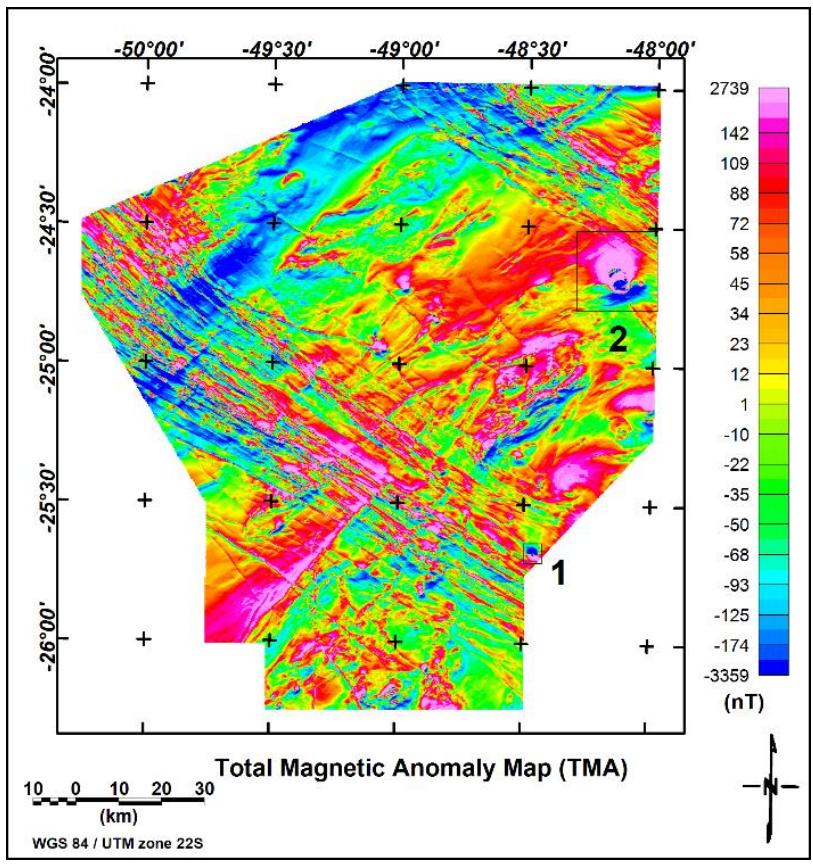

Figure 2 - Regional total magnetic anomaly (TMA) map on Ponta Grossa Arch, pointing out Canoas Anomaly (1, reverse polarization) and Jacupiranga (2, normal polarization) anomalies.

\section{Results}

Figure 2 shows the regional magnetic anomaly map throughout PGA, and dipolar anomalies can be observed on alkaline occurrences referred in Figure 1. Most of them are strongly supported by outcrops (e.g. Ruberti et al., 2005). However, the study area is located on a coastal plain, and the magnetic source lies covered by Quaternary deposits (Canoas Anomaly in Fig. 1).

The Canoas Anomaly range is from $-1060 \mathrm{nT}$ to $564 \mathrm{nT}$, with peak-to-peak amplitude just over $1600 \mathrm{nT}$ (Fig. 3). It is a typical reverse polarization anomaly and can be compared with Juquiá Anomaly (Fig. 4) as a reverse anomaly on PGAAP.

Similarly, the source of the Registro Anomaly, located immediately to the south of the Juquiá alkaline complex (JQ, Fig. 1), is covered by alluvial sediments of the Ribeira do Iguape River. Mantovani et al. (2005) investigated in detail this anomaly, originally interpreted by Ferreira and Algarte (1979) as a possible new alkaline intrusion.

ASA calculated anomaly (Fig. 5) shows a semi-circular feature crossed by linear NW-SE trends. From ASA, the vertical integration (VIAS) presents a more continuous and circular anomaly (Fig. 6). 
The zero isocurve of VIAS (Fig. 7) outlines a round feature, with an approximately $6 \mathrm{~km}$ in diameter.

Using Euler Deconvolution ( $S I=2)$, we did an experiment for source depths. From TMA, we noticed most significant depth values between $400 \mathrm{~m}$ and $1200 \mathrm{~m}$ (Fig. 8). VIAS transform was also used to investigate the Canoas Anomaly showing results between $1000 \mathrm{~m}$ and $2000 \mathrm{~m}$, with a significant peak around $1300 \mathrm{~m}$ (Fig. 8).

According to Euler stats (Fig. 8), VIAS tends to have deeper results than TMA analysis. This pattern is in some way expected since the vertical integration on magnetic data aims to emphasize deep magnetic sources (Silva, 1996). Moreover, long-wavelengths were a bit increased with VIAS transform, as shown on the synthetic model in Paine et al. (2001). This amplification may influence on Euler calculations.

In order to exemplify the correlation between TMA, ASA and VIAS, an S-N profile is presented in Figure 9. We observe that VIAS curve envelopes ASA signal and reduces high frequencies. Both are in good correlation with TMA as well.

Figure 10 shows the spatial relationships between Canoas Anomaly and gravimetric/magnetic ground profiles from Castro (2007). The sampling intervals of the gravimetric and magnetic profiles were $500 \mathrm{~m}$ and $25 \mathrm{~m}$, respectively. The residual Bouguer anomaly is $+14 \mathrm{mGal}$ and magnetic peak-to-peak amplitude is around $10000 \mathrm{nT}$. It is noticed a conspicuous correspondence between airborne and ground gravimetric/magnetic anomalies (Fig. 10).

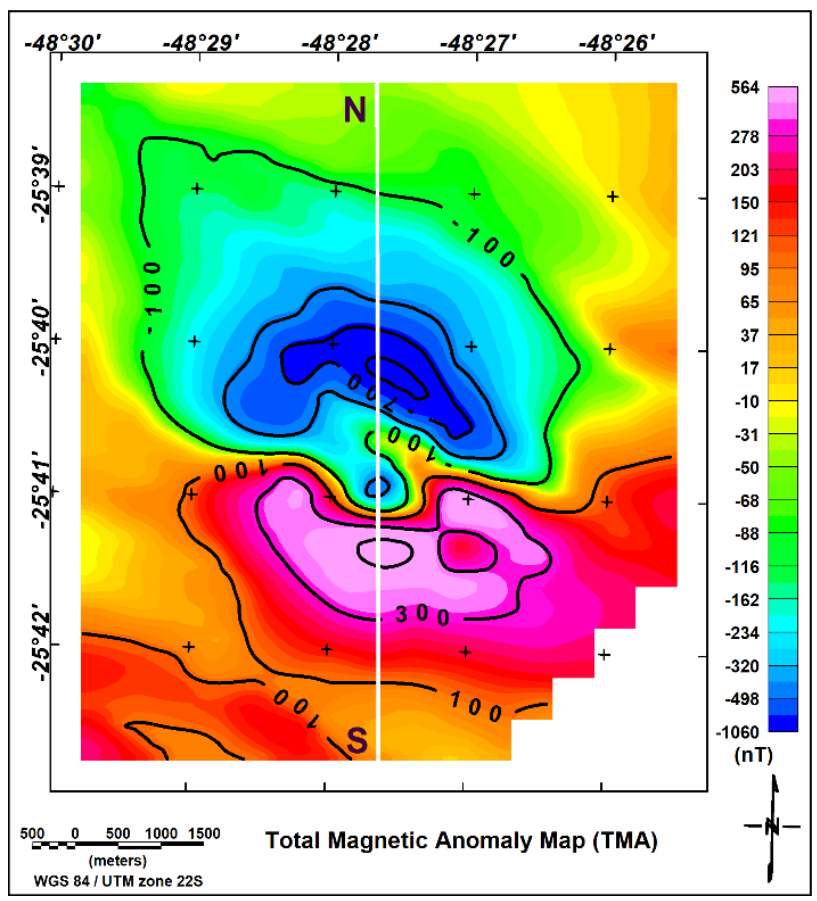

Figure 3 - Canoas total magnetic anomaly (TMA) map. See S-N profile in Figure 9.

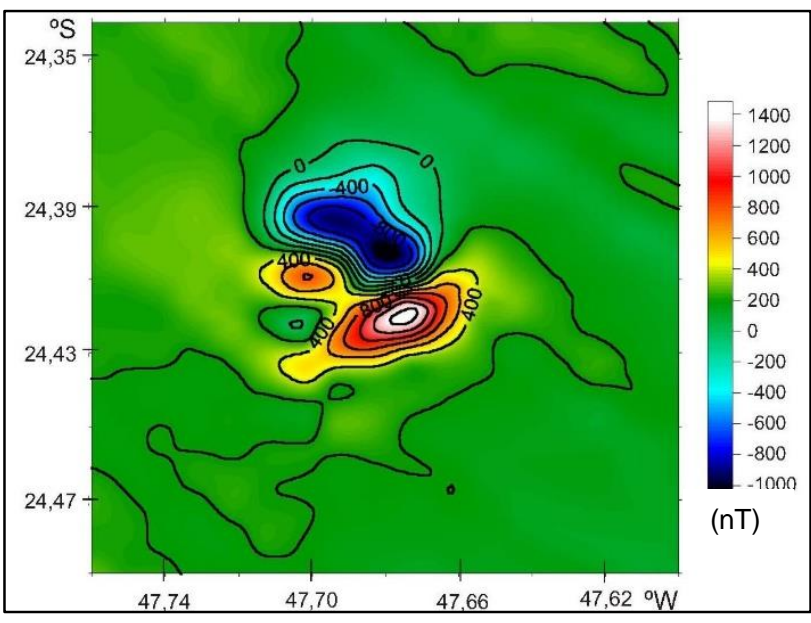

Figure 4 - Juquiá total magnetic anomaly (TMA) map (Ernesto and Marques, 2000).

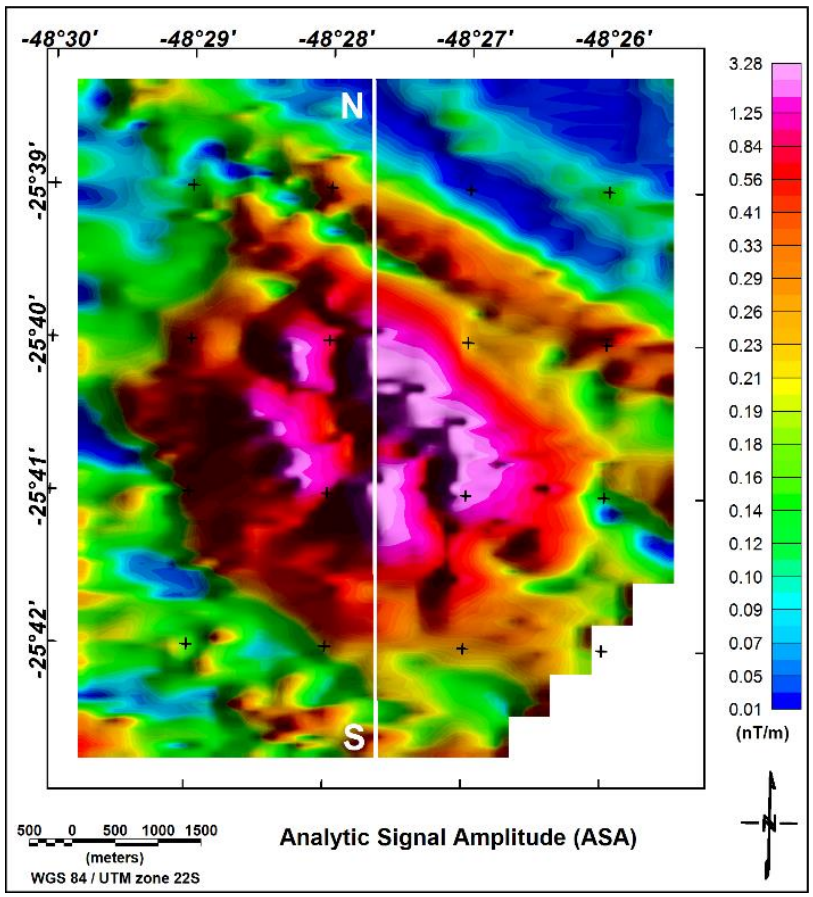

Figure 5 - Canoas analytic signal amplitude (ASA) map. See $S-N$ profile in Figure 9. 


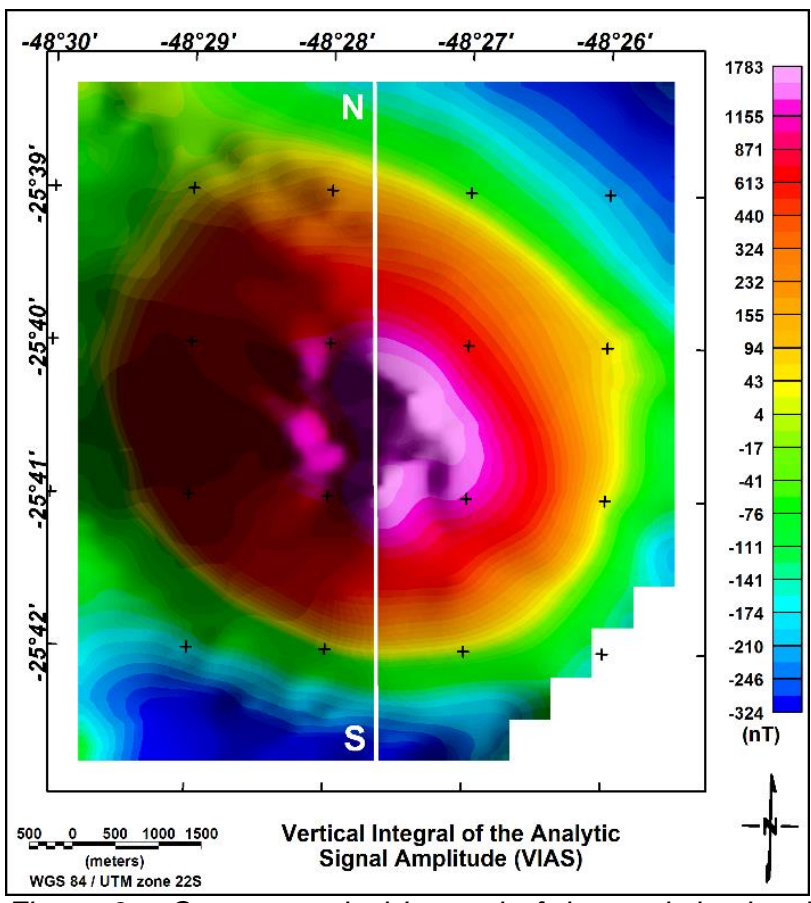

Figure 6 - Canoas vertical integral of the analytic signal amplitude (VIAS) map. See S-N profile in Figure 9.

\section{Discussion and Conclusion}

The studied magnetic anomaly is quite similar to other distinctive dipolar occurrences on Ponta Grossa Arch (PGA), which are typical from the Ponta Grossa Arch Alkaline Province (PGAAP). Therefore, the Canoas Anomaly can be considered a signature from alkaline occurrence, which may be incorporated on the PGAAP. Unfortunately, geological evidences from the magnetic source are unavailable since its alluvial sand cover (Fig. 1).

We observed that the Canoas anomaly has a reverse polarization (Fig. 3). This type of polarization is not the most common signature for alkaline bodies on PGAAP but is similar to the Juquiá Anomaly (Fig.4) on Guapiara Subprovince. However, from its location (Fig.1), it can be considered as part of the São Jerônimo-Curiúva Subprovince.

Euler calculation for the TMA (blue dots in Figure 7) shows a tendency according to NW-SE direction, typical of the tectonic control of diabase dykes and alkaline rocks (Figs. 1 and 2).

From VIAS anomaly, the obtained depth results were higher than TMA Euler values (Figs. 7 and 8). However, the significant Euler solutions are centered on Canoas Anomaly (red dots in Figure 7). This is in agreement with the pipe-like geological model.

Additionally, we compared the studied magnetic feature with ground geophysical data from Castro (2007). As a result, the Canoas Anomaly fits quite well on the main magnetic and gravimetric anomalies (Fig. 10).

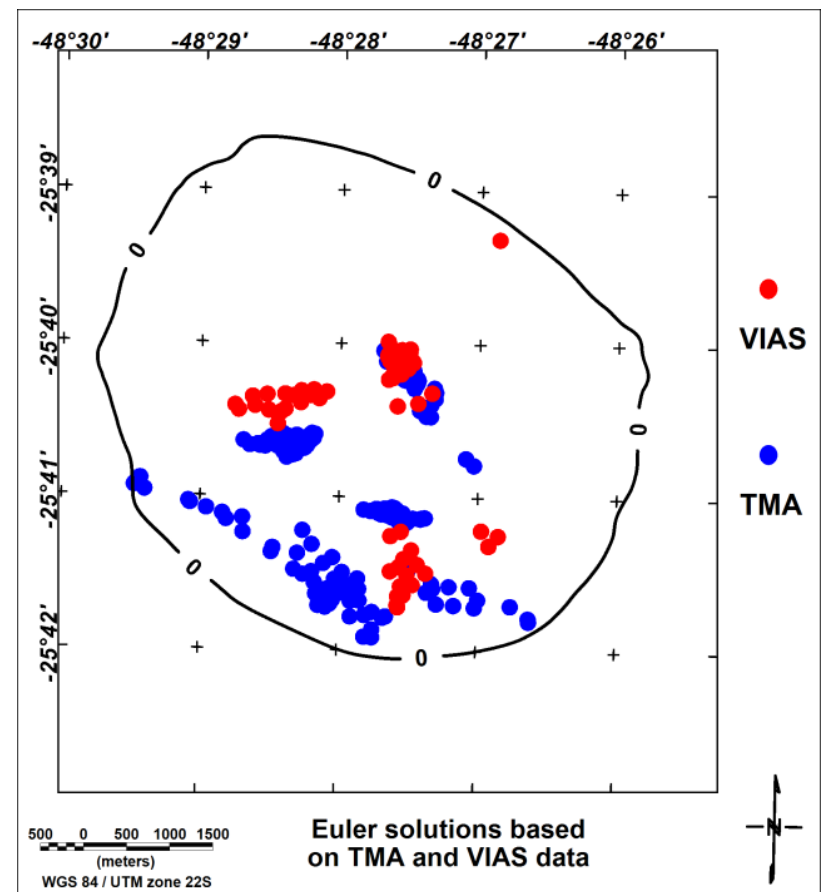

Figure 7 - Euler solutions map $(S I=2)$. Zero isocurve from VIAS map (Fig. 6).

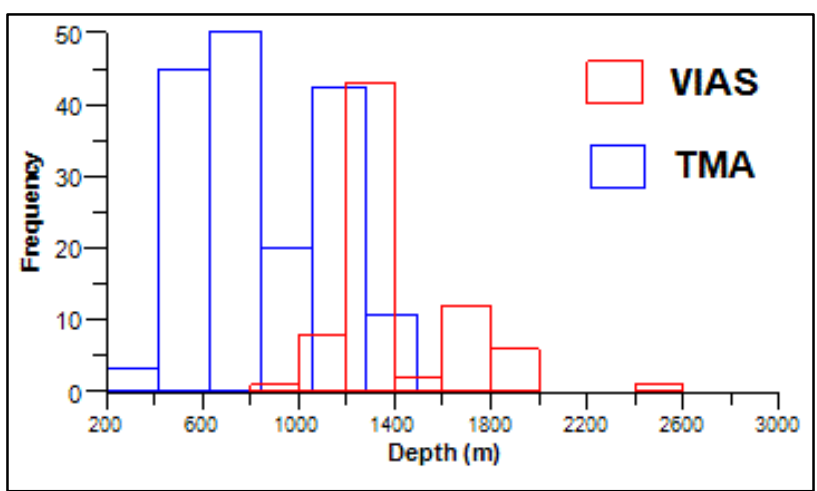

Figure 8 - Euler depth solutions $(S I=2)$ of the Canoas Anomaly. Note that TMA values are more scattered than VIAS results.

The characterization of the Canoas Anomaly and its interpretation as a likely new alkaline intrusion related to the Ponta Grossa Arch Alkaline Province, which does not present any geological indications on the surface, is the principal contribution of this work.

\section{Acknowledgments}

This research was supported by CAPES - Ministry of Education Brazil, Graduate Program in Geology - Federal University of Paraná (UFPR) and Laboratory for Research in Applied Geophysics (LPGA-UFPR). F.J.F. Ferreira acknowledges the grant from National Council for Scientific and Technological Development (CNPq), under contract 306978/2015-6. 


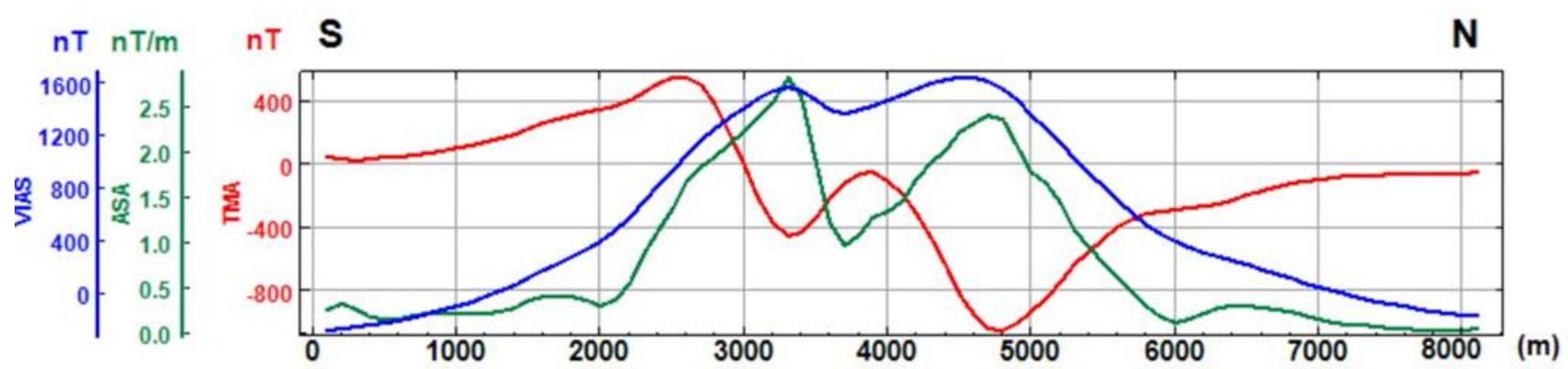

Figure 9-TMA, ASA and VIAS profiles (respective locations in figures 3, 5 and 6).

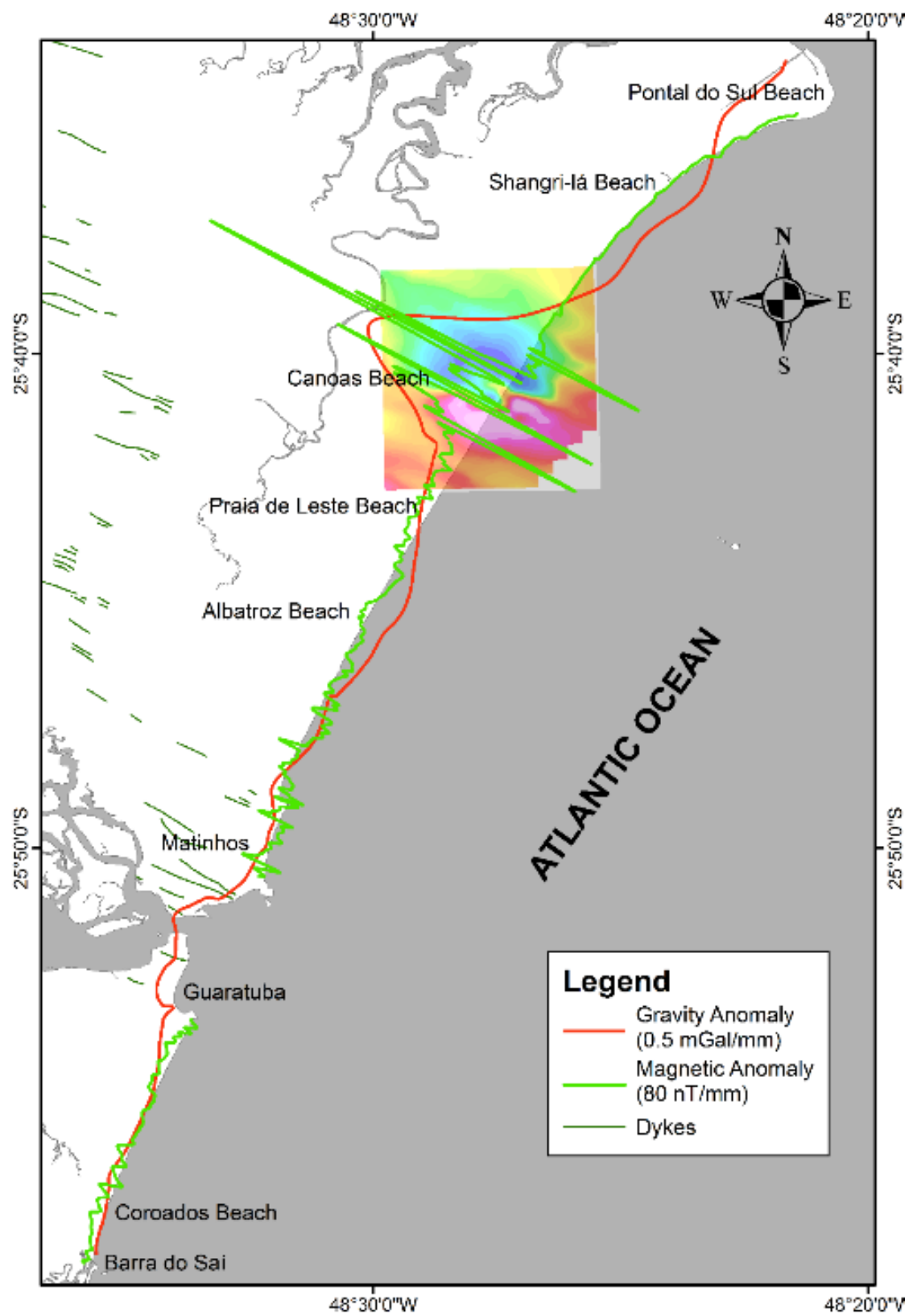

Figure 10 - Spatial relationships between Canoas airborne magnetic anomaly and ground gravimetric/magnetic profiles (modified from Castro, 2007). 


\section{References}

Almeida, F.F.M., 1983. Relações tectônicas das rochas alcalinas mesozóicas da região meridional da Plataforma Sul-Americana. Revista Brasileira de Geociências 13, 139158.

Almeida, F.F.M., 1986. Distribuição regional e relações tectônicas do magmatismo Pós-Paleozóico do Brasil. Revista Brasileira de Geociências, 16(4), 325-349.

Almeida, V.V., Janasi, V.A., Heaman, L.M., Shaulis, B.J., Hollanda, H.B.M., Renne, P., 2017. Contemporaneous alkaline and tholeiitic magmatism in the Ponta Grossa Arch, Paraná-Etendeka Magmatic Province: Constraints from U-Pb zircon/baddeleyite and $40 \mathrm{Ar} / 39 \mathrm{Ar}$ phlogopite dating of the José Fernandes Gabbro and mafic dykes. Journal of Volcanology and Geothermal Research, in press.

Blakely, R.J., 1996. Potential theory in gravity and magnetic applications. Cambridge University Press, Cambridge, 441p.

Castro, L. G. 2007. Modelo gravimétrico-magnético do Gráben de Paranaguá-PR. Dissertação de Mestrado. Universidade Federal do Paraná, 92p.

CPRM, 2011. Projeto Aerogeofísico Paraná-Santa Catarina. Companhia de Pesquisa de Recursos Minerais (Geological Survey of Brazil). Relatório Final do Levantamento e Processamento dos Dados Magnetométricos e Gamaespectrométricos, v.1, 88p.

Ernesto, M., Marques, L.S., 2000. Investigando o interior da Terra. In: Teixeira, W., Toledo, M.C.M., Fairchild, T.R., Taioli, F. (Eds.). USP Oficina de Textos, 4, 63-82.

Ferreira, F.J.F., Algarte, J.P., 1979. O comportamento aeromagnético-cintilométrico das principais rochas alcalinas dos estados de São Paulo e Paraná. Annals, II, Simpósio Regional de Geologia, Rio Claro, 2, 195-208.

Ferreira, F.J.F., 1982. Alinhamentos estruturaismagmáticos da região centro-ocidental da Bacia do Paraná e seu significado tectônico. IPT, São Paulo, 1217,143-166.

Ferreira, F.J.F., Daitx, E.C.; Moraes, M.C., 1984. Nova manifestação do magmatismo mesozóico associada ao arco de Ponta Grossa: o complexo gabróide de Barra do Estrela. In: Congr. Bras. Geol., 34, Rio de Janeiro, 1984. Anais... Rio de Janeiro, SBG, 4, 1693-1700.
Gomes C.B., Azzone R.G., Ruberti E., Vasconcelos P.M., Sato K.; Rojas G.E.E. 2018. New age determinations for the Banhadão and Itapirapuã complexes in the Ribeira Valley, southern Brazil. Brazilian Journal of Geology, 48 (ahead of print), 1-12.

Li, X., 2006. Understanding 3D analytic signal amplitude: Geophysics, 71, L13-L16.

Mantovani, M.S.M., Rugenski, A., Diogo, L.A., Shukowsky, W., 2005. Integrated geophysical investigation of a possible new alkaline occurrence in SE Brazil. Journal of South American Earth Sciences, 20, 259-266.

Marangoni, Y.R., Mantovani, M.S.M., 2013. Geophysical signatures of the alkaline intrusions bordering the Paraná Basin. Journal of South American Earth Sciences, 41, 8398.

Nabighian, M.N., 1972. The Analytic Signal of TwoDimensional Magnetic Bodies with Polygonal CrossSection Its Properties and Use for Automated Anomaly Interpretation. Geophysics, 37, 507-517.

Paine, J., Haederle, M., Flis, M., 2001. Using transformed TMI data to invert for remanently magnetized bodies. Exploration Geophysics, 32, 238-242.

Riccomini, C., Velázquez, V.F., Gomes, C.B., 2005. Tectonic controls of the Mesozoic and Cenozoic alkaline magmatism in central-southeastern Brazilian Platform. In: Comin-Chiaramonti, P., Gomes, C.B. (Eds.), Mesozoic to Cenozoic Alkaline Magmatism in the Brazilian Platform, pp. 31-55.

Ruberti E., Gomes C.B., Comin-Chiaramonti P., 2005. The alkaline magmatism from the Ponta Grossa Arch. In: Comin-Chiaramonti P. \& Gomes C.B. (eds.) Mesozoic to Cenozoic alkaline magmatism in the Brazilian Platform. São Paulo, Edusp/Fapesp, 473-522.

Silva, J.B.C., 1996. 2-D magnetic interpretation using the vertical integral. Geophysics, 61, 387-393.

Slavec, G.B., Mantovani, M.S.M., Shukowsky, W., 2001. Contribuição ao estudo do complexo de Juquiá. Revista Brasileira de Geociências 31(2), 203-210.

Thompson, D.T., EULDPH: A new technique for making computer-assisted depth estimates from magnetic data. Geophysics, 47, 31-37. 